\title{
The Implementation of Computer-Supported Collaborative Learning in Secondary Education
}

\author{
Vassilios Giannakos \\ Philologist, Secondary School Teacher, Med Education Sciences \\ University of the Aegean \\ Frinonos 14, 11632, Athens, Greece
}

Tel: 30-697-099-8688Ｅ-mail: premnt15007@rhodes.aegean.gr

\author{
Maria Darra \\ Assistant Professor, University of Aegean (corresponding author) \\ Dimokratias 1, 7th March Building, 85100, Rhodes, Greece \\ Tel: 30-693-242-5804 E-mail: darra@aegean.gr
}

Received: October 19, 2018 Accepted: November 13, 2018 Published: December 15, 2018

doi:10.5296/ijld.v8i4.13794

URL: https://doi.org/10.5296/ijld.v8i4.13794

\begin{abstract}
The main purpose of this survey is to investigate the effectiveness of Computer-Supported Collaborative Learning (CSCL) in the teaching of Modern Greek in Lyceum. The survey was carried out in the form of a field experiment, with one experimental group and one control group. An didactic intervention in the form of a training scenario was carried out. Fifty (50) students of the Second Class of Lyceum of the Prefecture of Attica were the sample of the survey. The survey was conducted from 10 October 2016 to 20 December 2016 and lasted thirteen hours. The results of the research revealed that, after the experiment, there was a positive change in the attitudes of the experimental group's students regarding the use and utility of the computer.
\end{abstract}

Keywords: CSCL, web 2.0, wiki, ICT, Literature

\section{Introduction}

Educational technology began a few decades ago in our country. Today, however, our society is based on information and technologies, which reform human activity in general and 
education in particular. Among other uses, technology in education re-shapes collaborative learning, as it can further facilitate cooperation by removing the factors of distance and time, through remote synchronous (simultaneous online connection between trainer and trainees) or communication (on-line connection between trainer and trainees at different times) (Mejias, 2006). But the most important contribution of technology to the educational process is controlling not only the result but also of process through which the collaborating team was led to the result. This way, the use of computers and the Internet opens new paths in education and cooperation in the educational process. Thus, the use of Computer-Supported Collaborative Learning (CSCL) is being shaped and implemented in recent years mainly through the use of web 2.0 applications.

In the field of education today, CSCL has made its presence felt, and so far, surveys show that its use can bring particularly positive results to the learning process. Examples of such studies are the ones by $\mathrm{Fu}$ et al. (2013) who reviewed a web 2.0 platform (wiki) as a computer-supported collaborative learning environment (CSCL) in the final grade of basic education. Also, Wang's research (2014), which investigated whether collaborating on a wiki can contribute to both language development and social interaction, thus emphasizing the potential of CSCL, as well as the research by Jeong et al. (2016) which is a meta-analysis of the research on the application of the CSCL method to STEM (Science, Technology, Engineering and Mathematics) education.

In the Greek educational reality, the surveys carried out are smaller in number and limited in range. They mainly relate to the exploration of the potential of a web 2.0 platform (wiki) in the creation of science simulation programs, the use of a wiki platform in e-learning, its influence in learning through two organized activities, synthetic work and web collaboration (Mitala, 2008; Chouliaras et al.,2011; Roussinos \&Tzimogiannis, 2011; Altanopoulou, 2011; Sivaka \& Ginoudi, 2013). However, there are very few studies in Greece concerning the use of CSCL during the educational process with educational activities in the classroom (Karystinakis, 2012; Geomelou, 2011).

There is, therefore, relatively little research into the involvement of ICT in the educational process through the use of CSCL. Especially in Greece, it doesn't revolve around language courses. This study aims to fill this gap as it involves the application of CSCL method to a language course within the classroom. The results given throughout its course will highlight an alternative aspect in the use of technology in the educational process. Hopefully it will encourage researchers to explore its further use in other teaching subjects and inform teachers about new possibilities of technology in education so as to be motivated to optimize it.

\section{Theoretical Framework}

Collaborative learning has been incorporated into education to exploit the benefits of collaboration and to socialize trainees. There are two categories of cooperative learning approaches in the literature; the socio-constructivist approach, based on Piaget's theories, and the socio-cultural approach, influenced by Vygotsky's theory, through the prism of collective intelligence (Slavin, 1995; 1996). 
Technology, as a cooperative mediator, should be seen not simply as a facilitator of collaborative learning but as a factor that reforms human action. Therefore, mediative technology could transform the nature of cooperation. On the other hand, advancements in the field of cognition and cognitive development leads to the acceptance of the social character of learning and the framework for cognitive activity (Littleton \& Light, 1999). Thus, the creation of cooperative activities around and through the computer begins, as cognitive theory points to the need to design environments that facilitate interaction and cooperative learning (Brown \& Campione, 1996; Vosniadou, 1996), making the development of computer-supported collaborative learning inevitable. The first appearance of computer-supported collaborative learning took place in 1989 in a NATO workshop and today it is one of the most prominent developing branches of Educational Technology (Karasavides \& Komis, 2008).

Constructivism argues that learning is an active process where the individual builds knowledge through observation, interpretation and exploration (Cooper, 1993). According to Warschauer and Healey (1998), the incorporation of Computer Assisted Language Learning (CALL) helps students learn in authentic and substantive situations. At the same time, Koschmann (1996) considers Computer-Supported Collaborative Learning as the fourth stage of the evolution of educational technology and integrates it into the social theories of social constructivism and socio-cultural theories.

Lipponen \& Lallimo (2004), in their attempt to find common points among successful examples of computer-assisted collaborative learning, emphasize on the role of designing the appropriate teaching method, on which cooperative technology will be based. They present the need for designed learning activities and point out the importance of the framework, the tool mediation and the practices followed (Karasavidis \& Komis, 2008). In this approach, the educator is transformed from a knowledge authority into a students' counselor in the discovery, construction and sharing of knowledge (Marantos, 2001; Lundin, 2008). An environment that implements CSCL enables students to take responsibility within the distinctive roles of a group. However, it requires a different culture in the classroom, as it supports knowledge through a different prism and requires a different approach from the teacher (Doyle, 1986). It is, thus, a difficult task, as enhancing students with learning responsibilities presents a reaction. Moreover, when students do not recognize a new situation as a lesson, they consider it to be a failure, which is attributed to the teacher (Kollias et al., In: Avouris et al., 2008).

Computer-Supported Collaborative Learning acquires new modern technological environments that mediate communication and support social interaction (Avouris et al., 2003), which are linked to the development of the internet and web 2.0 (Komis, 2004).

Web 2.0 technologies focus on users. They support student-centered teaching, as the wiki approach is a bottom-up approach (Astall, \& Cowan, 2016). On wiki platforms, users are also writers and knowledge is shared, creating the right conditions for collaboration and interaction (Hughes \& Narayan, 2009). The trainee from a passive receiver becomes an active creator and builds knowledge. It's a kind of site that allows all users to add, remove and 
change most of the content and share it with others. Its structure tends to be very simple, focusing on content and collaboration rather than on design. It has writing, discussion, database capabilities. It provides a postal system, a collaboration tool and a simple tool for creating multimedia / simple digital stories. At the same time, the wiki records every change by any user, allowing to observe any modification. It uses RSS so that users receive notifications for any content updates. This feature allows contact with other group or class students, but also with the teacher. Students become donors and not just recipients of knowledge, as they're allowed to participate in the distributed research communities expanding in space and time, beyond the lesson that takes place in the classroom (Mejias, 2006).

However, because users can modify the content of a wiki, the approval of such manipulation of information poses certain risks. Consequently, the wiki needs to be checked frequently, which is a time-consuming task for the teacher. Thus, many wikis require approval so that only group members can modify the content (Papadima-Sofokleous, 2009).

\section{Purpose and Research Questions}

The main purpose of this study is to investigate the effectiveness of the of Computer-Supported Cooperative Learning method's contribution in the teaching of Modern Greek Literature in Lyceum. In particular, the work aims to explore the contribution of the digital platform web 2.0 wiki pbworks but also of subsidiary applications and software- to the teaching of Modern Greek Literature in the Lyceum: a. to the development of a more positive attitude towards the computer as a tool for discovering and conquering knowledge; $b$. to the more effective achievement specific learning objectives, according to the curriculum of this course.

The individual research questions that we' 11 attempt to answer are:

1): Can the integration of an online collaborative tool such as web 2.0 platform wiki pbworks, as part of the implementation of a training scenario, contribute to a more positive attitude of students towards the use and usefulness of the computer?

2): Can the use of an online collaborative tool such as the web 2.0 related wiki pbworks contribute to the more effective achievement of students' teaching objectives in the course of Literature?

3): Is there a difference in the more effective achievement of the teaching objectives in the Literature course, between the students who used the wiki pbworks platform in their teaching, and those whose teaching was not supported by this tool?

\section{Methodology}

This study is a field experiment, with an Experimental Group and a Control Group. The experimental group was taught by the cooperative method and each group of students had a computer with an internet connection (workstation), while the control group was taught by the cooperative method without access to a computer. The survey was conducted from 10 October 2016 to 20 December 2016 and lasted thirteen teaching hours. 


\section{Macrothink

The sample selected for the experiment consists of fifty (50) second grade General Lyceum students in the Prefecture of Attica. They are two of the six General Education classes of this particular Lyceum. They were selected as such, because Literature, which is the research field, is a General Education course. Specifically, the twenty-five students (25) of the B1 class are the Experimental Group. The twenty-five (25) B2 class students are the Control Group. In the experimental group there are 8 boys and 17 girls (32\% and 68\%, respectively). In the control group there are also 8 boys and 17 girls (32\% and $68 \%$, respectively). The groups, therefore, are gender-equivalent, but the number of girls is superior. The age of the pupils varies between 16-17 years, as they are students of the second grade of Lyceum.

The two groups (experimental group and control group) are as equal as possible in terms of performance. In order to evaluate this, we took into account the students' performance in the course of Modern Greek Literature, as well as their overall performance during the previous school year. It should be noted that the previous year's grades were used as a criterion for assessing the pupils' initial school performance. The survey started in October, at the beginning of the new school year, therefore, those were the most recent indicators of their performance.

Web 2.0 platform, wiki pbworks as well as individual subsidiary tools (word processor, presentation software, video creating software, internet, browser software) are used as the main technological tools.

Pre and post tests were conducted to evaluate the didactic intervention as well as teacher's evaluations of the activities, implemented by using the right tools. More specifically, the research tools used in the context of this research are the following:

a. Student Profile Configuration Questionnaire.

This questionnaire is an adjustment from the information found on the following websites:

National Center for School Engagement

The Vermont Department of Education's official web site

\section{CESNational}

Cengage Learning, 2008.

\section{The Texas Center for Educational Technology}

The questionnaire is used to gather data and information about the characteristics of the experiment's participants and the factors that concern them and will be taken into account when drawing conclusions. It was distributed to the experimental group.

In particular, the questionnaire consists of three sections and uses Likert, multiple choice and Yes/No type questions. It concerns: demographics, gender and age of the participants, students' views on the role, use and usefulness of the computer in every aspect of life, the type of internet use, the place of internet use and their knowledge of Internet safety and computer use at school. 
After the experiment, the students of the experiental group were redistributed the first section of the questionnaire, related to student's views on the use and usefulness of the computer. The aim is to investigate whether integrating an online collaborative tool, such as the web pbworks platform, into the teaching process helps to create a more positive attitude among students regarding the use and usefulness of the computer, which is our first research question.

b. Student Activity Assessment Rubrics, which are completed by the teacher separately for each group and for each student after the experiment and the completion of the activities.

The activity assessment rubrics used in this survey are an adaptation from: https://www.sandi.net/staff/i21-interactive-classroom/i21-interactive-classroom (Last accessed on 16/9/2016).

In detail, the Activities Assessment Rubric was used to evaluate the teams - both the Experimental Group and the Control Group - on the activities based in the course worksheets.

A rubric is filled out to evaluate the activities assigned for each group. It evaluates the factors of structure, content, image usage, multimedia use, comprehension. This assessment is conducted by the teacher to determine whether the learning goals designed in the curriculum are achieved and to what extent.

The conclusions of the rubric results will be used to answer the second research question, ie whether the use of an online collaborative tool such as the wiki 2.0 pbworks platform, which belongs to the web 2.0 category, helps students achieve the learning objectives of Modern Greek Literature course more effectively.

c. Activity sheets, used during the implementation of the training scenario. In this survey's scenario there are used sixteen worksheets. Six for the first and six for the second teaching section conducted with six working groups and four for the third teaching section conducted with four working groups. By using these sheets, students are encouraged to investigate and get involved in a range of activities aimed at specific learning objectives.

d. Observations from the teacher / researcher, noted throughout the experiment. In this study, the observer is in the room where the experiment is conducted. The participants are familiar with his identity and his role in the experiment. During the course of the experiment the teacher also participates as a coach. The observation is a combination of semi-structured and unstructured data collection methods. There is a topic agenda, but there is no specific way to collect data. It is also likely that data, the significance of which was not foreseen, may occur.

In this survey, we test Computer-Supported Collaborative Learning (CSCL) in the teaching of Modern Greek Literature in General Lyceum. The experiment is carried out through the implementation of educational intervention, in the form of a training scenario. The scenario is divided into three sections, which represent three different literary texts. It's based on the $5 \mathrm{E}^{*}$ Instructional Model (Bybee, 1997) founded on the constructivism-based Atkin / Karplus (1962) model. Its purpose is to encourage students to enrich their initial thinking with additional knowledge and eventually change any misconceptions they have. Model $5 \mathrm{E}$ is 


\section{Al Macrothink}

International Journal of Learning and Development

ISSN 2164-4063

2018, Vol. 8, No. 4

divided into five learning phases: Engagement, Exploration, Explanation, Elaboration, Evaluation.

In the context of this survey, there are some limitations worth mentioning. The most significant limitation is that the sample of the survey consisted of 50 students and is therefore relatively small. The use of a larger sample would reinforce the survey's credibility. At the same time, there were time constraints which did not allow any further duration of the research program. The survey began after issues among teachers were resolved and the course timetable was stabilized in the school where the survey was conducted. It ended with the coming of the December holidays, right before the completion of the winter semester. Even though the research period was 2.5 months, the actual time of the survey was relatively limited as a total of 13 teaching hours was dedicated to the survey. Finally, the course curriculum was relatively small, as it consisted of three literary texts.

\section{Results}

Research Question 1: Attitudes of students in the experimental group regarding the use and utility of the computer.

The investigation is carried out through a three-module questionnaire. The results from the first module of the questionnaire, which has to do with students' attitudes regarding the use and utility of the computer before the didactic intervention, is presented in Table 1 below.

Table 1. Opinions and attitudes of the experimental group students on the use of computers before the didactic intervention

\begin{tabular}{|c|c|c|c|c|c|c|}
\hline \multicolumn{7}{|c|}{$\begin{array}{l}\text { Opinions and attitudes of the experimental group students on the use of computers before the didactic } \\
\text { intervention }\end{array}$} \\
\hline Possible Answers & $\begin{array}{l}\text { I completely } \\
\text { disagree }\end{array}$ & $\begin{array}{l}\text { I } \\
\text { disagree }\end{array}$ & $\begin{array}{l}\text { I neither } \\
\text { agree nor } \\
\text { disagree }\end{array}$ & $\begin{array}{l}\text { I } \\
\text { agree }\end{array}$ & $\begin{array}{l}\text { I completely } \\
\text { agree }\end{array}$ & Total \\
\hline \multirow{2}{*}{ I like using the computer } & 0 & 1 & 4 & 10 & 10 & 25 \\
\hline & $0 \%$ & $4 \%$ & $16 \%$ & $40 \%$ & $40 \%$ & $100 \%$ \\
\hline \multirow{2}{*}{ I get tired when using a computer } & 1 & 11 & 11 & 2 & 0 & 25 \\
\hline & $4 \%$ & $44 \%$ & $44 \%$ & $8 \%$ & $0 \%$ & $100 \%$ \\
\hline \multirow{2}{*}{$\begin{array}{l}\text { Someone who knows how to use } \\
\text { a computer can find a good job. }\end{array}$} & 0 & 2 & 9 & 11 & 3 & 25 \\
\hline & $0 \%$ & $8 \%$ & $36 \%$ & $44 \%$ & $12 \%$ & $100 \%$ \\
\hline \multirow{2}{*}{$\begin{array}{l}\text { I'm focused on what I do when } \\
\text { i'm using a computer }\end{array}$} & 3 & 0 & 9 & 11 & 2 & 25 \\
\hline & $12 \%$ & $0 \%$ & $36 \%$ & $44 \%$ & $8 \%$ & $100 \%$ \\
\hline \multirow{2}{*}{$\begin{array}{l}\text { Computers offer me the } \\
\text { possibility to learn a lot of new } \\
\text { things. }\end{array}$} & 0 & 0 & 3 & 16 & 6 & 25 \\
\hline & $0 \%$ & $0 \%$ & $12 \%$ & $64 \%$ & $24 \%$ & $100 \%$ \\
\hline \multirow{2}{*}{$\begin{array}{l}\text { I believe that school courses } \\
\text { could become more interesting if } \\
\text { teachers incorporate a computer } \\
\text { in the lesson. }\end{array}$} & 0 & 3 & 4 & 10 & 8 & 25 \\
\hline & $0 \%$ & $12 \%$ & $16 \%$ & $40 \%$ & $32 \%$ & $100 \%$ \\
\hline
\end{tabular}




\begin{tabular}{|c|c|c|c|c|c|c|}
\hline \multirow{2}{*}{$\begin{array}{l}\text { It is very important to know how } \\
\text { to use a computer. }\end{array}$} & 0 & 1 & 7 & 10 & 7 & 25 \\
\hline & $0 \%$ & $4 \%$ & $28 \%$ & $40 \%$ & $28 \%$ & $100 \%$ \\
\hline \multirow{2}{*}{$\begin{array}{l}\text { I feel very comfortable when I } \\
\text { use a computer. }\end{array}$} & 1 & 0 & 5 & 12 & 7 & 25 \\
\hline & $4 \%$ & $0 \%$ & $20 \%$ & $48 \%$ & $28 \%$ & $100 \%$ \\
\hline \multirow{2}{*}{$\begin{array}{l}\text { The thought of using a computer } \\
\text { causes me negative feelings. }\end{array}$} & 17 & 7 & 0 & 0 & 1 & 25 \\
\hline & $68 \%$ & $28 \%$ & $0 \%$ & $0 \%$ & $4 \%$ & $100 \%$ \\
\hline \multirow{2}{*}{$\begin{array}{l}\text { I think it takes a lot of time to } \\
\text { complete an assignment using a } \\
\text { computer. }\end{array}$} & 2 & 7 & 11 & 5 & 0 & 25 \\
\hline & $8 \%$ & $28 \%$ & $44 \%$ & $20 \%$ & $0 \%$ & $100 \%$ \\
\hline \multirow{2}{*}{$\begin{array}{l}\text { Using a computer can make } \\
\text { somebody feel frustrated. }\end{array}$} & 4 & 7 & 9 & 2 & 3 & 25 \\
\hline & $16 \%$ & $28 \%$ & $36 \%$ & $8 \%$ & $12 \%$ & $100 \%$ \\
\hline \multirow{2}{*}{$\begin{array}{l}\text { When i have to complete a task, } \\
\text { I'll use a computer as little as } \\
\text { possible. }\end{array}$} & 5 & 9 & 7 & 3 & 1 & 25 \\
\hline & $20 \%$ & $36 \%$ & $28 \%$ & $12 \%$ & $4 \%$ & $100 \%$ \\
\hline \multirow{2}{*}{ Using a computer is difficult. } & 5 & 13 & 7 & 0 & 0 & 25 \\
\hline & $20 \%$ & $52 \%$ & $28 \%$ & $0 \%$ & $0 \%$ & $100.00 \%$ \\
\hline
\end{tabular}

From the processing of the second section of the questionnaire, which relates to the attitudes of the experimental group regarding the use of the internet, it appears that they use the computer every day (96\%) with an average time of 2-3 hours per day (44\%). They use social network sites $(36 \%)$ to exchange instant messages $(80 \%)$ from home $(48 \%)$ and from their mobile phones $(48 \%)$.

Processing the third section of the questionnaire, which refers to the views of the experimental group regarding the use of computer at school, it appears that ICT lessons at school are poor $(80 \%)$. The use of computers in other courses is little or unsatisfactory $(96 \%)$, as the school has only one computer room with 18 computers, while students can't use the computers at all times (96\%). After the didactic intervention was completed, the first section of the questionnaire was re-distributed to the experimental group, aiming at exploring the contribution of a web 2.0 web tool to the more positive attitude of the students regarding the use and utility of the computer.

Comparing the experimental group students' attitudes, before and after the experiment, there are differentiations, as shown in the parentheses. They enjoy using the computer $(80 \%+4 \%=$ $84 \%)$, they do not consider it tiresome $(92 \%+4 \%=96 \%)$ they feel comfortable $(74 \%-2 \%=$ $72 \%)$, computer use does not cause them negative feelings $(96 \%-4 \%=92 \%)$, they don't get frustrated when they use a computer $(80 \%+8 \%=88 \%)$ they consider computer use easy $(72 \%+4 \%=76 \%)$, they use the computer for their assignments $(56 \%+8 \%=64 \%)$, while the degree of concentration is above average $(52 \%+12 \%=68 \%)$. Computer Literacy is important for finding a job $(56 \%+16 \%=72 \%)$, knowing how to use a computer is important $(88 \%$ $-28 \%=88 \%)$ and so is its contribution to acquiring new knowledge $(88 \%-2 \%=86 \%)$. The participants are interested in using the computer in all school subjects $(72 \%+12 \%=84 \%)$, while their attitudes on the time needed to complete a task on the computer are neither positive nor negative $(44 \%+20 \%=64 \%)$. 


\section{Macrothink}

International Journal of Learning and Development

ISSN 2164-4063 2018, Vol. 8, No. 4

Research Question 2: Achievement of learning objectives of the experimental and control groups.

For evaluating the pupils of the experimental group, a rubric was used to assess the tasks and activities in which both student groups participated. This rubric examines whether the use of an online, collaborative tool such as wiki pbworks platform contributes to the more effective achievement of pupils' learning objectives in the Literature course. The teacher completed six assessment rubrics of the students' designed activities, one for each of the six teams. The results of this assessment are shown in Table 2 below. To the question "To what extent do you agree with the following suggestions on student assessment?" the answers of the respondents in relation to specific dimensions of the existing evaluation system, which were asked to evaluate, are presented in Table 2 below.

Table 2. Results of the assessment rubric of group activities of the experimental group during didactic intervention

\begin{tabular}{lllllll}
\hline GROUP & 1 & 2 & 3 & 4 & 5 & 6 \\
\hline SCORE / 25 & 21 & 21 & 21 & 23 & 25 & 21 \\
SCORE / 100 & 84 & 84 & 84 & 92 & 100 & 84 \\
\hline
\end{tabular}

Table 3. Analytical results of the assessment rubric of group activities of the experimental group during didactic intervention

\begin{tabular}{llllllll}
\hline GROUP & 1 & 2 & 3 & 4 & 5 & 6 & GROUP \\
\hline SCORE / 25 & 21 & 21 & 21 & 23 & 25 & 21 & SCORE / 25 \\
SCORE / 100 & 84 & 84 & 84 & 92 & 100 & 84 & SCORE / 100 \\
GROUP & 1 & 2 & 3 & 4 & 5 & 6 & GROUP \\
SCORE / 25 & 21 & 21 & 21 & 23 & 25 & 21 & SCORE / 25 \\
SCORE / 100 & 84 & 84 & 84 & 92 & 100 & 84 & SCORE / 100 \\
GROUP & 1 & 2 & 3 & 4 & 5 & 6 & GROUP \\
\hline
\end{tabular}

The results of the control group's assigned activities assessment rubric evaluated by the teacher are presented in Table 4 below.

Table 4. Results of the assessment rubric of the experimental group's activities during didactic intervention

\begin{tabular}{lllllll}
\hline GROUP & 1 & 2 & 3 & 4 & 5 & 6 \\
\hline SCORE / 25 & 21 & 21 & 21 & 23 & 25 & 21 \\
SCORE / 100 & 84 & 84 & 84 & 92 & 100 & 84 \\
\hline
\end{tabular}


More specifically, the results are shown by criterion in Table 5 below.

Table 5. Results of the assessment rubric of the experimental group's activities during didactic intervention

\begin{tabular}{llllllll}
\hline GROUP & 1 & 2 & 3 & 4 & 5 & 6 & GROUP \\
\hline SCORE / 25 & 21 & 21 & 21 & 23 & 25 & 21 & SCORE / 25 \\
SCORE / 100 & 84 & 84 & 84 & 92 & 100 & 84 & SCORE / 100 \\
GROUP & 1 & 2 & 3 & 4 & 5 & 6 & GROUP \\
SCORE / 25 & 21 & 21 & 21 & 23 & 25 & 21 & SCORE / 25 \\
SCORE / 100 & 84 & 84 & 84 & 92 & 100 & 84 & SCORE / 100 \\
GROUP & 1 & 2 & 3 & 4 & 5 & 6 & GROUP \\
\hline
\end{tabular}

Research Question 3: Differentiation in achieving the learning objectives between the students of the two groups

Table 6, below, compares the results of the activities assessment rubric, which was completed by the teacher for each group

Table 6. Comparative presentation of the students' activities evaluation results on both the experimental group and the control group

\begin{tabular}{lll}
\hline & EXPERIMENTAL GROUP & CONTROL GROUP \\
\hline Group / Criteria & Overall Score $/ 30$ & Overall Score/30 \\
Structure & 28 & 26 \\
Content & 28 & 24 \\
Image Use & 26 & 6 \\
Multimedia & 22 & 6 \\
Comprehension & 28 & 26 \\
\hline
\end{tabular}

\section{Discussion of Research Results}

\subsection{Research Question 1}

The study of the first section of the questionnaire demonstrates that students of the experimental group have a positive attitude towards computers. They think that a person who acquires computer skills can find a good job and they state that when they work on a computer, they are concentrated on what they do. They believe that school lessons would become more interesting if teachers incorporated computers in their teaching and consider computer knowledge to be very important, saying that they feel very comfortable when they use it. They do not express either positive or negative attitudes about the time needed to complete an assignment on the computer, and they do not believe that using it can cause 
frustration to someone. Finally, they state that they will not avoid using a computer in an assignment, as they consider that using a computer is not difficult.

The data analysis of the questionnaire's second section showed that students use the computer and the internet for an average of 2-3 hours per day, while a significant percentage spends more than 4 hours per day on the computer. They prefer to use social network sites, especially for exchanging messages, and they do so both from their computers and their mobile phones. The data analysis of the questionnaire's third section reveals that ICT courses are not satisfactory, while computer use in other school courses is almost non-existent.

The result comparison of the first questionnaire section, which was distributed before and after the didactic intervention shows that after the experiment students have a more positive attitude regarding the use of a computer, but they feel slightly less comfortable. They get less frustrated, they consider computer use easier than they originally believed, and incorporate it more in their assignments, being more concentrated when they do so. They consider computer knowledge more important for finding a job and their attitudes are more positive towards its use and its contribution it to acquiring new knowledge. They believe even more that computers should be incorporated in all school courses. Also there is an increase in the percentage of undecided people on how much time it takes to complete an assignment on the computer.

These results are partly in line with the relevant literature, according to which the rapid growth of the internet and web 2.0 technology takes computer use to new dimensions (Avouris et al., 2008). At the same time, it's in line with a survey conducted by Syvaka and Ginoudis (2013), which demonstrated that students developed co-operational skills, the building of knowledge, the use of new technologies, problem solving and implementation of innovative ideas by using the same technology tool.

\subsection{Reasearch Question 2}

The assessment rubrics, completed by the teacher, regarding the activities of the experimental group, showed that the students' assignment results were good to excellent, as the scores ranged from $84 / 100$ to $100 / 100$. Apparently the teams' results on the criteria of structure, content and comprehension were overall very good, accumulating 28/30 points for each. As far as image use is concerned, they showed a slightly lower performance of $26 / 30$ points, as they appeared to have difficulty locating images and using them within time limits. The lowest performance is clearly the use of multimedia, in which the teams gathered 22/30 points as the search and use of multimedia in a task required more time, practice and a better knowledge of the computer and the internet.

The results are in line with the survey of Altanopoulou (2011), which demonstrated the efficiency of the digital wiki platform in the learning process and the improvement in the results of the university students who participated, while their attitudes on the whole process were positive.

The assessment rubric results of the control group's activities, filled out by the teacher, draw to the conclusion that the work rate of the teams was moderate to good, as the scores ranged 
from $44 / 100$ to $68 / 100$. Apparently, the teams' results on structure, content and comprehension were overall very good, gathering 28/30 points per criterion. The structure was clear, the content was rich, as they had understood the subject and the demands of the activities. The group's poorest performance was apparent in the field of image use, scoring 6 points, as they could not find pictures, print them, and place them in their assignments. As far as multimedia use is concerned, the teaching scenario instructed that groups had to collaborate beyond school hours to research and present a part of their work using multimedia. However, this was not feasible, as they gathered a score of only $6 / 30$. The result is partly in accordance with the research of Jeong et al. (2016), a meta-analysis of studies on the application of the CSCL method to STEM. They found out that the CSCL method is effective not only during the cognitive process but also on an emotional-social level and that younger students have benefited more from it.

\subsection{Research Question 3}

The result comparison of the experimental group and the control group, based on the teacher's evaluation of each group's activities, shows that the experimental group achieved higher results in the overall score. The overall score ranges from $22 / 30$ points to $28 / 30$ points per criterion, as opposed to the control group ranging from $6 / 30$ to $26 / 30$ degrees per criterion.

The results are in line with the literature, since Harel (1991) states that, nowadays, it is becoming all the more accepted that the combination of constructivist theories is the best choice, when designing an educational software (and similar pedagogical and didactic activities). Meanwhile, they correspond with the studies of Ruth and Houghton (2009) and Karystinaki (2012), who found out that the wiki platform changes the perspective of collaboration and encourages a more cooperative lesson, by approaching a more constructive learning model. Students who used the wiki collaborative platform appeared more prone to get involved in the lesson -which they found enjoyable- and contribute to their group, while at the same time their performance was better than that of the control group.

\section{Conclusions}

The first research question points to a more positive attitude of the experimental group's students towards the use and utility of the computer compared to their views before the experiment, ranging from small to larger depending on the field. Therefore, it shows that the didactic intervention with the simultaneous use of web 2.0 digital wiki pbworks platform resulted in the reinforcement of the students' positive attitude, regarding the use and utility of the computer.

As to the second research question, it becomes clear that the experimental group managed to approach and understand to a very large extent all three literary texts taught with CSCL. The fact that students got in touch with this new approach and successfully met its requirements, confirms the achievement of the learning objectives. The reason behind the students' small difficulty in image and especially multimedia use, is mainly their relative lack of experience in such tasks. The control group's performance was lower than that of the experimental group. The control group's capabilities were limited due to the absence of a computer and the 
internet. Through observation of both teams, the teacher found out that, although all the participants were willing to accomplish the goals, the control group did not match the performance of the experimental group. Their point of deficiency was mainly the use of images and multimedia, as students in the control group were only able to search for images, print them, and put them in their assignments from home. Regarding the use of multimedia, they had to search for material or format it themselves and then save it in portable storage media in order to present it on the school computer. Those parameters led to the discouragement of students in the control group, as they made image and multimedia use in the assignments particularly hard for them.

Finally, regarding the third question, the comparison of the assessment rubric results of both groups' activities, led to the conclusion that the collaborative method in teaching works better and achieves higher results in the cross-curricular approach of Literature when supported by the use of a computer and the internet. Also, web 2.0 digital wiki collaboration platform, wiki pbworks, is a useful tool for the educator.

\section{Suggestions for Further Research}

The constraints mentioned earlier in the chapter of methodology lead to the following suggestions for further research.

The survey could be carried out once more so as to extract safer conclusions. The sample could be divided into four groups, two experimental groups and two control groups. In the course of the experiment, an experimental group and a control group will be subjected to pre-evaluation and post-evaluation, while the second pair of groups will be submitted to a single post-evaluation. This method will lead to more effective measurements and more valid comparisons.

According to the results, the participants were not particularly familiar with computer assignments. It would be interesting to work on a sample which is more familiar with computer assignments or on a sample with low degree of familiarity.

Additionally, the sample, as mentioned, consisted of nine boys and sixteen girls in each group. The fact that the number of girls was twice the number of boys may have had an effect on the survey's results. It would be interesting to have a similar research in a sample with an equal number of boys and girls.

It would also be interesting to further examine this topic by using another online collaboration tool to determine the value of the tool used in this study by comparing them.

Finally, this tool could be used in all grades of the Lyceum, Gymnasium and even the two final grades of Primary School, under certain conditions, as pupils in the lower classes are likely to be more familiar with online collaborative tools.

\section{References}

Altanopoulou, P. (2011). Evaluating the learning effectiveness of educational activities using wikis (Thesis, Department of Educational Sciences and Early Childhood Education. Patras: 
University of Patras).

Astall, C., \& Cowan, J. (2016). Experiences of Using Wiki as a Participatory Learning Tool in Teacher Education. American Journal of Educational Research, 4(6), 459-471.

Atkin, J. M., \& Karplus, R, (1962). Discovery or Invention? The Science Teacher, 29(5), 45-51. Retrieved from http://www.jstor.org/stable/24146536

Avouris, N., Dimitracopoulou, A., \& Komis, V. (2003). On Analysis of Collaborative Problem Solving: An Object-Oriented Approach. Computers in Human Behavior, 19(2), 147-167. https://doi.org/10.1016/S0747-5632(02)00056-0

Avouris N., Karagianidis X. \& Komis V., (2008). Collaborative Technology: Systems and Collaboration Models for Working, Learning, Communities of Practice and Creation of Knowledge. Athens: Klidarithmos

Brown, A., \& Campione, J. (1996). Psychological theory and the design of innovative learning environments: On procedures, principles, and systems. In L. Schauble \& R. Glaser (Eds.), Innovations in learning: New environments for education (pp. 289-325). Mahwah, NJ: Lawrence Erlbaum Associates, Inc.

Bybee, R. W. (1997). Achieving scientific literacy: From purposes to practices. Portsmouth, NH: Heinemann.

Chouliara, O., Frentzou-Rodokanaki, M. \& Antoniou, K. (2011). The use of wikis in the classroom: the asynchronous education course, in 6th International Conference in Open \& Distance Learning. E Proceedings (Vol. 6, $\mathrm{n}$ 2B). Loutraki: Greece. https://doi.org/10.12681/icodl.656

Doyle, W. (1986). Classroom management techniques and students discipline. Handbook of Research on Teaching, 392-431. https://doi.org/10.1007/s13398-014-0173-7.2

Fu, H., Chu, S.\& Kang, W. (2013). Affordances and Constraints of a Wiki for Primary-school Students' Group Projects. Journal of Educational Technology \& Society, 16(4), 85-96. Retrieved from http://www.jstor.org/stable/jeductechsoci.16.4.85

Geomelou, A. (2015. Development of creativity in a digital collaborative learning environment to solve authentic problems. (Thesis, Department of Digital Systems. Piraeus: University of Piraeus).

Harel, I. (1991). Cognition and computing series. Children designers: Interdisciplinary constructions for learning and knowing mathematics in a computer-rich school. Westport, CT: Ablex Publishing.

Hughes, J., \& Narayan, R. (2009). Collaboration and Learning with Wikis in Post-Secondary

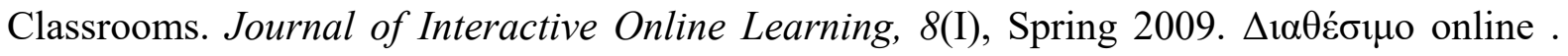



Jeong, H., Hmelo-Silver, C. E., Jo, K., \& Shin, M. (2016). CSCL in STEM education: Preliminary findings from a meta-analysis. Proceedings of the Annual Hawaii International 
Conference on System Sciences, 2016-March (April), 11-20. https://doi.org/10.1109/HICSS.2016.11

Karassavides I., \& Komis, V. (2008) Theoretical Issues to Support Collaboration and Learning in Avouris, N., Karagiannidis, Ch., Komis, V. (eds.), Collaborative Technology, Systems and Models of Collaboration for Working, Learning, Communities of Practice and Creation of Knowledge. Athens: Klidarithmos.

Karystinakis, I. (2012). The use of wikis in the teaching of computer science in secondary education (Thesis, Department of Digital Systems. Piraeus: University of Piraeus).

Kollias, V., Vamvakousis, X., et al. (2008). The Role of Teachers in Cooperative Learning. in Avouris, N., Karagiannidis, Ch., Komis, V. (eds.), Collaborative Technology, Systems and Models of Collaboration for Working, Learning, Communities of Practice and Creation of Knowledge. Athens: Klidarithmos. Retrieved from http://olympias.lib.uoi.gr/jspui/handle/123456789/26583

Komis, V. (2004). Introducing the application of information and communication technologies in education. Athens: New Technologies Publishing (New Tech Pub).

Koschmann, T. (1996a). Paradigm shifts and instructional technology. In T. Koschmann (Ed.), CSCL: Theory and practice of an emerging paradigm (pp. 1-23). Mahwah, NJ: Lawrence Erlbaum.

Lipponen, L., \& Lallimo, J. (2004). From Collaborative Technology to Collaborative Use of Technology: Designing Learning Oriented Infrastructures. Educational Media International, 41(2), 111-116. https://doi.org/10.1080/09523980410001678566

Littleton, K. \& Light, P. (1999). Learning with Computers: Analysing Productive Interactions. Journal of Computer Assisted Learning, 15(4), 332. https://doi.org/10.4324/9780203282311

Lundin, R. W. (2008). Teaching with wikis: Towards a Networked Pedagogy. Computers and Composition, 25(4), 432-448. https://doi.org/10.1016/j.compcom.2008.06.001

Marantos, P. (2001). Education and Mass Media. Athens: Patakis.

Mejias, U. (2006). Teaching social software with social software. Innovate, 2(5). Retrieved May 24, 2016, from http://innovateonline.info/index.php?view=article\&id=260).

Mitalas, A. (2008). Teaching using new technologies: Artificial Intelligence, web 2.0: Blogswiki - webquest. (Thesis, University of the Aegean. Rhodes: University of the Aegean).

Papadima-Sofokleous, S. (2009). Call Wiki «New Technologies Conference (Web 2.0) and Libraries (Library 2) ». Paper presented at the meeting of Cyprus Association of Librarians Information Scientists (KEVEP).

Roussinos, D. \& Tzimoyannis, A. (2011). Design and study of a mixed e-learning environment through wiki: A case study on first-year university students. 6th International Conference Open \& Distance Learning. eProceedings (Vol 6, n 2B). Loutraki. Greece. https://doi.org/10.12681/icodl.663 


\section{Macrothink}

International Journal of Learning and Development

ISSN 2164-4063 2018, Vol. 8, No. 4

Ruth, A., \& Houghton, L. (2009). The wiki way of learning. Australasian Journal of Educational Technology, 25(2), 135-152. https://doi.org/10.14742/ajet.1147

Slavin, R. E. (1995). Cooperative learning: Theory, research, and practice (2nd ed.). Boston: Allyn \& Bacon.

Slavin, R. (1996). RESEARCH FOR THE FUTURE Research on Cooperative Learning and Achievement: What We Know, What We Need to Know. Contemporary Educational Psychology, 69(1), 43-69. https://doi.org/10.1006/ceps.1996.0004

Syvaka, T. \& Ginoudi, A. (2013). The Contribution of "Social" Web 2.0 Tools to Building Collaborative Knowledge. 7th International Conference in Open \& Distance Learning. eProceedings (Vol 7, n 2B). Athens. Greece. https://doi.org/10.12681/icodl.647

Vosniadou, S. (1996). Towards a revised cognitive psychology for new advances in learning and instruction. Learning and Instruction, 6(2), 95-109. https://doi.org/10.1016/0959-4752(96)00008-4

Wang, Y. C. (2014). Using wikis to facilitate interaction and collaboration among EFL learners: A social constructivist approach to language teaching. System, 42(1), 383-390. https://doi.org/10.1016/j.system.2014.01.007

Warschauer, M., \& Healey, D. (1998). Computers and language learning: An overview. Language Teaching, 31(2), 57-71. https://doi.org/10.1017/S0261444800012970

\section{Copyright Disclaimer}

Copyright for this article is retained by the author(s), with first publication rights granted to the journal.

This is an open-access article distributed under the terms and conditions of the Creative Commons Attribution license (http://creativecommons.org/licenses/by/4.0/). 